講演

\title{
E-1.3.2 演色委員会を中心としで
}

専門会員森礼於*

今回 CIE の総会での最重要な成果は 1959 年提案の 10 度視野スペクトル三刺激值が承認され，その使用が勧告 されたことであろう．これに次ぐものとして筆者の立場 から考觉ると，E-1.3.1で新しい均等色差三次元座標と して LMN 系 (WUV系) を勧告したこと，およびE-1. 3.2 で演色性評価の CIE 暫定方法を定めたことがあげ られる.ここでは最後の問題に焦点をしばって総会前後 の様子をお伝えする．ただし全部を正確な資料に基づい て述べるわけではないので, 若干の䛊りが含まれると思 われる. 後日発行される公式の議事録との相違は筆者の 語学力の限界として和許し願いたい.

\section{1. 光源の演色性を測定表示する CIE 暫定方法}

まず結論的に採択された CIE Interim Method の大 略を紹介する，以下は総会後の専門委員間の連絡滛的 修正を加えた 1963-9-16 の英文修正案(Nickerson) に よる.

（1）目 的 試検色方法（物体色を基準光源 で照明したときと試料の光源で照明したときとの色ずれ 量から演色性を評価する）によって光源の演色性を測定 表示する方法を規定する. 個々の光源の日常測定には, この方法と一致する結果を与えるような簡便法を用いて もよい。

（2）適用範囲単色光またはそれ近い光源を 除くほとんぞすべての一般照明用光源滴用される.

（3）評 価 一般演色評点 (General Colour Rendering Index）に補足として一組の特殊演色評点 (Special Colour Rendering Indicies)を加えたもので 行なう.

\section{(4) 評価手順}

（4. 1) 一般的注意 (省略)

（4.2）基準光源 とくにことわらない限り，色 温度 $6,000^{\circ} \mathrm{K}$ 以下の試料光源化対しては近似する色温 度の黑体放射を用い, 色温度が $6,000^{\circ} \mathrm{K}$ より高い試料 光源に対しては Abbot-Gibson の空光の分光分布の采 列を用いる。

$\dagger$ On the E-1.3.2 Color Rendering Committee

* 東京芝浦電気(株)中央研究所

Vol. 47 No. 12
（4. 3）基準光源の許容差 できるかぎり試料光源 から 5 ミレッド差以内の基準光源を選ばなければならな い.どの向に対してもこれ以上の色差が試料光源と基 準光源との間にあるときは，結果の演色評点はあまり正 確でなくなる。

（4.4）試験色 一般演色評点を計算するための 8 種の試験色の分光反射率を第 1 表に示寸．特殊演色評点 には他の試験色を追加して用いてもよい，高彩度の赤， 黄, 緑, 青を代表するもの拉よび顔色と葉の色を代表す るものとしてマンセル色紙で与えられる特殊試験色を第 2 表に示す.

（4．5）試験色の $1931 \mathrm{CIE}$ 三刺激值の求め方 試 料光源の十分正確な分光放射測定結果之試験色の分光反 射率とから, 光源自体と試験色との色度座標を $x, y$ で 小数点下 4 けた目まで計算する。

（4.6） $1960 \mathrm{CIE}-\mathrm{UCS}$ 座標への変換 $u, v$ 來標 への変換は次式により小数点下 4 汀た目まで求める。

$$
\begin{array}{ll}
u=\frac{4 X}{X+15 Y+3 Z} \text { または } & u=\frac{4 x}{-2 x+12 y+3} \\
v=\frac{6 Y}{X+15 Y+3 Z} \text { または } & v=\frac{6 y}{-2 x+12 y+3}
\end{array}
$$

\section{（5）演色評点の計算}

（5.1） 演色評点の表示記号 （省略）

（5．2）一般演色評点の計算 一般演色評点 $R_{a}$ は 次式から計算する。.

$$
R_{a}=100-4.6 \overline{\Delta E}_{a}
$$

この式は $R_{a}=100-3.7 \times 10^{3} \overline{\Delta E_{u}, v}$

および $\overline{\Delta E_{a}}=800 \Delta \overline{E_{u}, v}$

から求めたものであり, $\overline{\Delta E_{a}}$ は次式で計算する.

$$
\overline{\Delta E_{a}}=\Sigma \Delta E_{a} / 8
$$$$
\Delta E_{a}=800\left[\left(u_{0}, i-u_{k, i}^{\prime}\right)^{2}+\left(v_{0, i}-v^{\prime}{ }_{k, i}\right)^{2}\right]^{1 / 2} \cdots \cdots(2)
$$

ここで $u_{0, i}, v_{0, i}$ は試験色 $(i)$ の基準光源の下での UCS 來標であり, $u_{k, i}^{\prime}, v_{k, i}^{\prime}$ は次式による.

$$
u_{k, i}^{\prime}=u_{k, i}+\left(u_{0}-u_{k}\right) ; v_{k, i}^{\prime}=v_{k, i}+\left(v_{0}-v_{k}\right)
$$

ここで $u_{k}, i, v k, i$ は試跧色( (i)の試料光源の下での UCS 座標であり， $u_{o}, v_{o}, u_{k}, v_{k}$ はそれぞれ基準光源 $(0)$ お よび試料光源 $(\mathrm{K})$ の UCS 座標である.

式(1)の係数は IES (米国) 委員会の $3,000^{\circ} \mathrm{K}$ けい光 


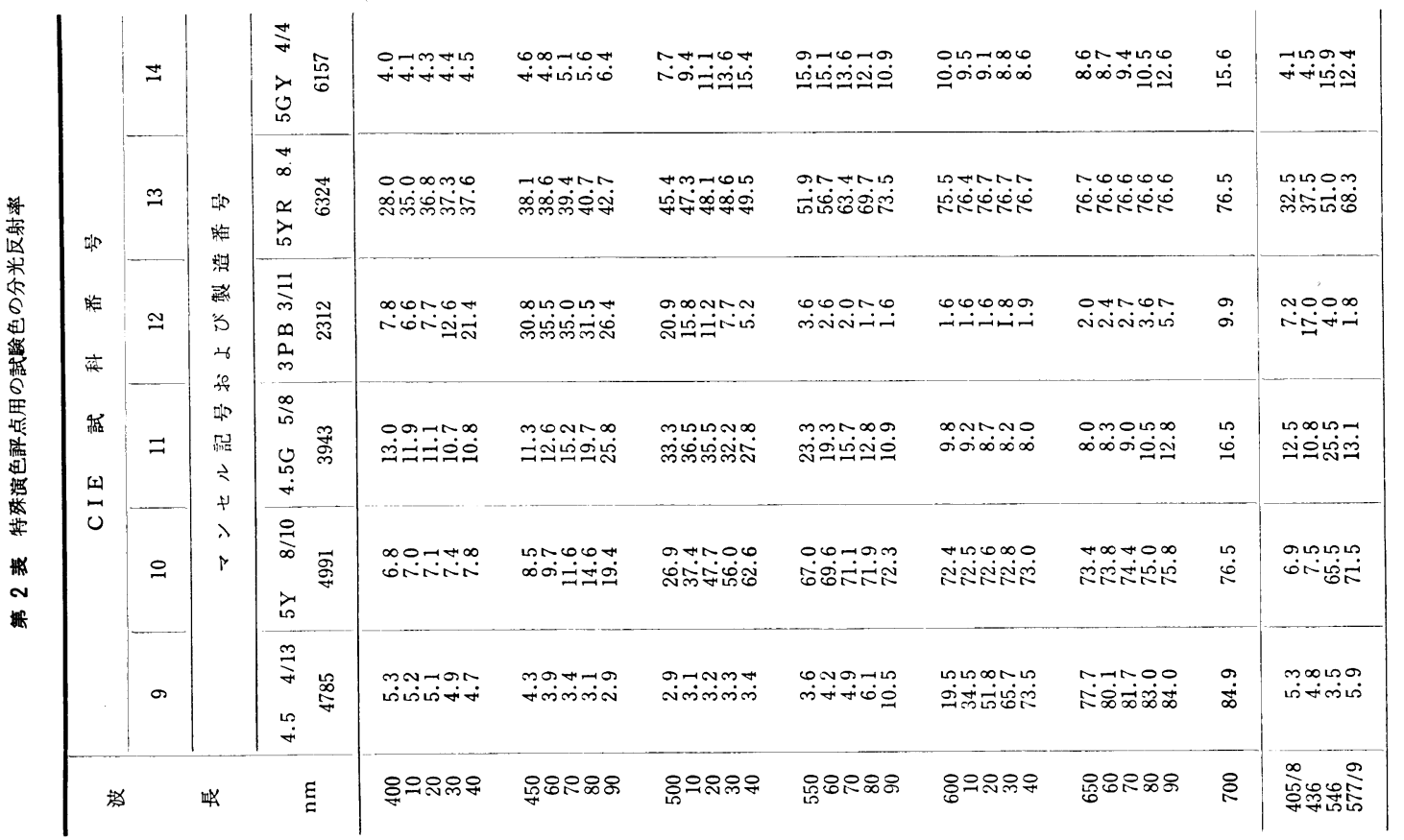

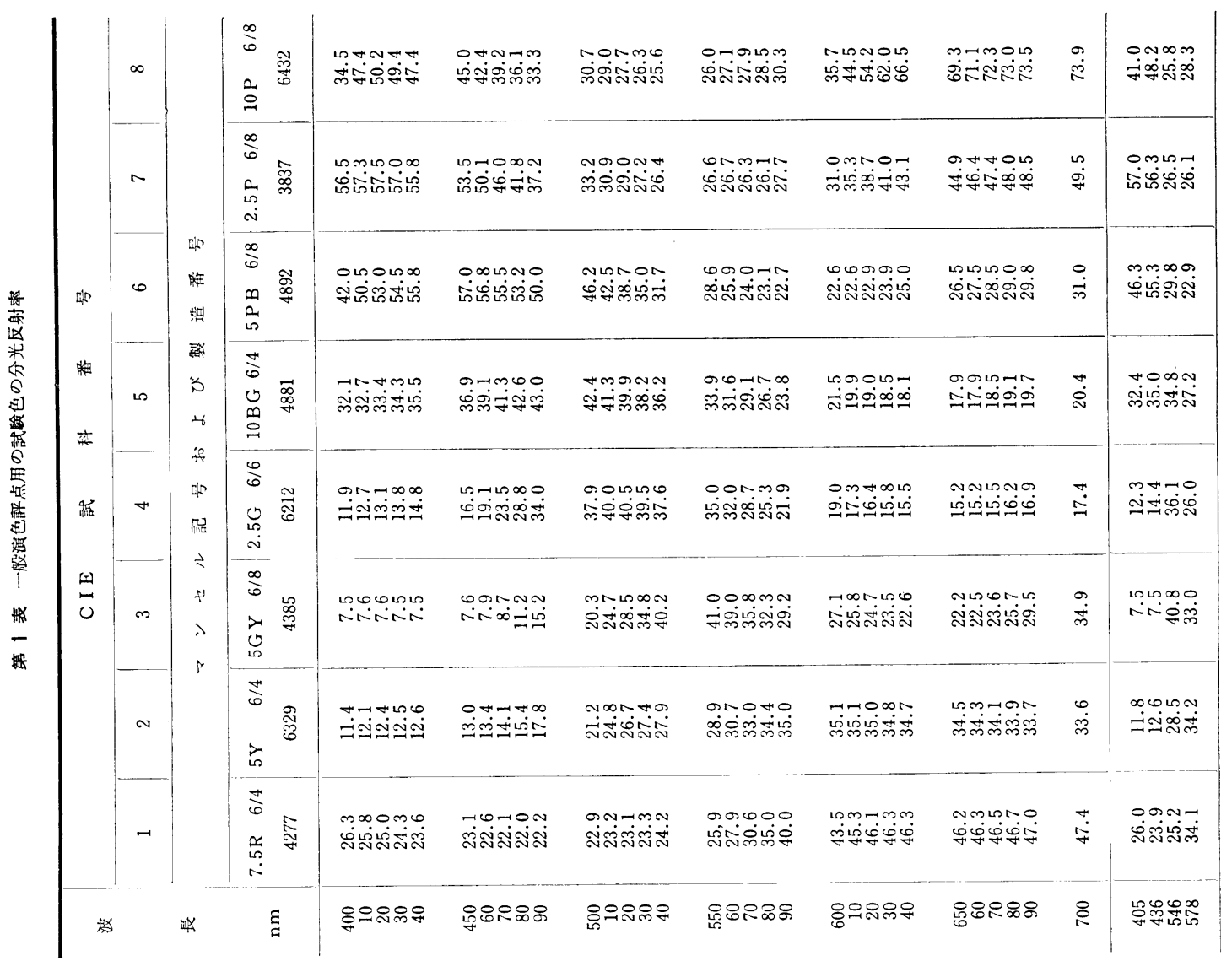


ランプを電球を基準として評価した評点が 50 になるよ うに定好たものである。また $\Delta E_{u, v}$ にか孫数 800 は $\Delta E_{a}$ の単位を NBS 単位に近似的に等しくするためのも のであり，これによって試験色 Nos. 1-8 の $\Delta E_{a}$ は $\Delta E_{i}$ とも近似的に等しくなる.

（5．3）特殊演色評点の計算 第 1 表の一般用の試 験色または他のものとくに第 2 表の試験色について求め る、第 1 表, 第 2 表以外の試験色を用いるときには正確 な分光反射率を必要とする．計算は次式による.

$$
\begin{aligned}
& R_{i}=100-4.6 \Delta E_{i} \\
& \Delta E_{i}=\left\{\left[W_{k, i}-W_{o, i}\right]^{2}\right. \\
& +13^{2}\left[W_{k, i}\left(u_{k, i}-u_{k}\right)-W_{o}, i\left(u_{0}, i-u_{0}\right)\right]^{2} \\
& \left.+13^{2}\left[W_{k, i}\left(v_{k, i}-v_{k}\right)-W_{o, i}\left(v_{o, i}-v_{o}\right)\right]^{2}\right\}^{1 / 2} \cdots(3) \\
& \text { ここで } \\
& W_{k, i}=25 Y_{k, i}{ }^{1 / 3}-17 ; \quad W_{o, i}=25 Y_{o, i}{ }^{1 / 3}-17 \cdots(4)
\end{aligned}
$$

$W$ は明度係数であって添字は (5.2) と同じである. 係 数 13 は標準状態に拈ける $W$ と $u, v$ の単位を等しくす るためのものである。また $W$ が 61 (試験色 1-8) で明 度のずれがないときには $\Delta E_{i}$ は $\Delta E_{a}$ に等しくなる。

\section{2. 会 議 前の動向}

このような CIE 暫定方法が定められた背景を少し述 べなければならない. 1948 年の CIE では演色性評価用 のスペクトルバンド1をを暫定的に定多ていたが，これは 批判の対象になっていて，E-1.3.2ではこれまで提案さ れた各種の演色性評価方法2)を参考にして統一的な方法 を検討していた．最近オランダの Ouweltjes の論文 ${ }^{3)}$ などが評価されて, 今度定めるものは試験色方法による ことが承認されていた。

昨年に至って米国の IES の演色小委員会では, その Interim Method 4)を完成し，またドイッでは DIN61695) として演色評価方法を成文化し，この両者が E-1.3.2の 資料として提出された. 両者とも試験色方法によるもの であるが, 米国案はマンセルバリュー6の中程度の彩度 の 8 試験色（第 1 表）の $u, v$ 色度図上の平均ずれ量か ら演色值を求刍るのであり, ドイッ案は高彩度の色紙 や演色で重要な肌色などを加えた 8 試騟色（第 2 表に 2 色を加えたもの）の Adams 色空間での明度を含めたず れ量から個々の演色值と平均の演色值とを求めるもので ある. このよらな根本的には一致するが相当に異なった ものを含んでいる二つの原案からどのような CIE 方法 を定めるかということが今回の演色部会にかけられた最 大の課題であった.

\section{3. 予備専門委員会}

本会議前の E-1.3.2 専門委員会 (Presession) は 6 月14日（金）の午前, 午後と 6 月16日（月）の午前の 3 回にわたって開催されたが，筆者の出席したのは16日朝

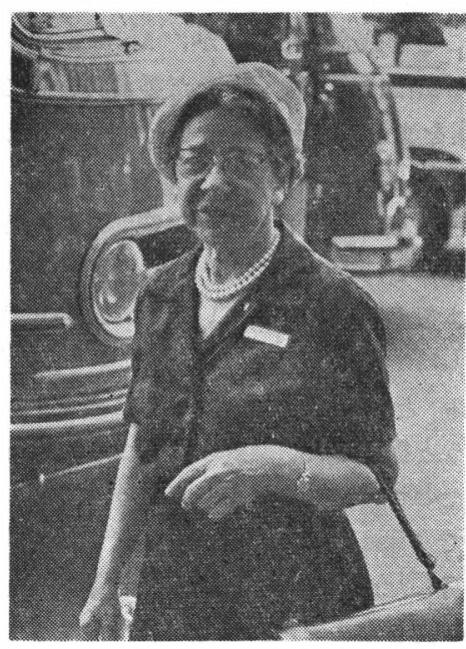

第 1 図 Miss Nickerson 演色部会も終えバス旅行へ出発前の一時

からの最後の会合である．定刻近くHofburg 宮殿の屋 根裏に通ずるような階段を上っていくと専門委員会が同 時に三つぐらい開かれる小会議室があって, そこの廊下 で納谷氏に出会い緊張感がややほぐれる．室内にはいる とすでに面識のある Dr. Wyszecki, Dr. Sandarsのほ か一目でそれとわかる委員長 Mr. Münch, Miss Nickerson さらに Dr. Judd, Dr. Richter の顔が見える。 Mr. Münch は Miss Nickerson および Miss Schulz と忙がしそうに下打合わせしている中をたって歓迎の意 を表してくれた.この間にあいさつしながら Drs. Frühling, Bodmann, Crawford, Winch, Ouweltjes, Reilley 等々の顔と名前を結びつける。まず気ついたこ とは各国から Exparts および Corresponding Members のほかに多くの権威者や若手の研究者が Consultants として参加していることである.

まもなく開会が宜せられ前日の議事の確認とその成文 化にはいった. 納谷氏の説明と会の様子で一般演色值と しては米国案がほとんど採択されたことを知り，筆者は ドイッ案を支持したいと考えていた意見を述べる機会を

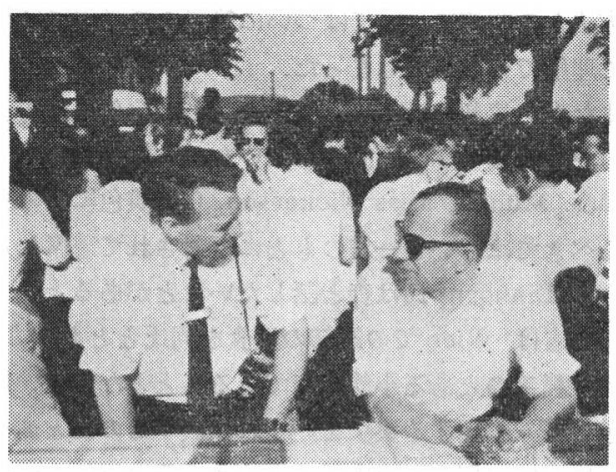

第 2 図土䍜午後のバス旅行で Dr. Wyszecki (右) および Dr. Johnes (N. P. L.) 
失なったことを残念に感じたが，Münch 氏には自国案 に固執する気配は全くなく，ただ委員長としていかによ く CIE 案をまとめるかといらことだけに専念して抢ら れる様子であった。

特殊演色評点は三次元の等色差空間における色ずれを もとにすることになっていて，いかなる色差式を用いる かが当日までの懸案になっていた.ここでDr. Wyszecki が立って LMN 系を説明し,これは E-1.3.1でも recommendation として承認したので，これを用いるのがよ いであろうと提案した. Miss Nickerson は「1.3.1 で 承認されたのですね」と念をおしてがら簡単に賛成し た.ここで Miss Schulz が彼女独自の色差式を黒板に かいて説明したが CIE で認めた Uv 系などとの関連が なく，その良さもよくわからないのでたらまらのらちに 否決されてしまった.

骨子がほとんどまとまって，条文の独仏文案のまとめ 役の分担を相談しているころ，Dr. Crawford, Dr. Winch はスペクトルパンド方法もすてがたいことを論

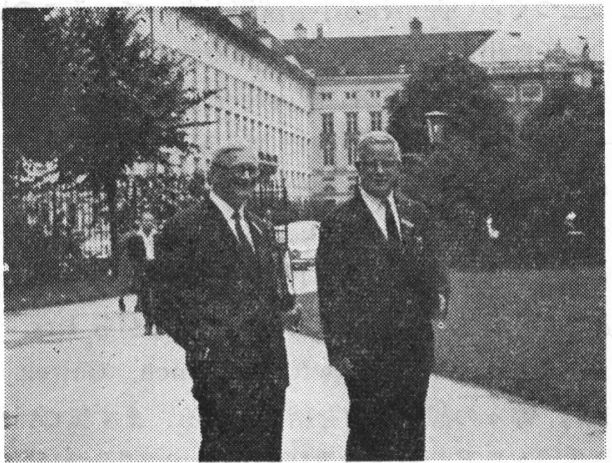

第3図会場脇の公園で

Dr. Winch(左) および Dr. Waldram(右)

じた. 英国は 1948 年の CIE スペクトルパンドを工業 規格に採用している国であって，最近でも実験に基つい て新しいスペクトルバンド方法を提案していることは筆 者も知るところであったが，この英国の主張と今回の暫 定方法との関連についてはついに筆者の話学力では最後 まで理解できないでしまった。

また南ア連邦の Dr. Einhorn はこの演色評価方法に は、色の好ましさが考慮されていないと批判した。しか し Mr. Münch, Miss Nickerson らに演色に好みを入 れるべきではないと一言のもとに反対されて着席した。 散会後 Einhorn 氏は森と話したいことがあるというの で，筆者はWien での最初の昼食を同氏とともに Hof burg 裏手のとある小飲食店でとることとなった，同氏 は色の好みに関する実験をいずれ発表するのだと述べ， 演色において好ましい方向へのずれもその反対もすべて 同じ重みで評価するなどとはナンセンスであると力説さ
れた。筆者もある程度までこれに賛成の意は表した後， まず演色の忠実性を数量化すべきことを述べながら， Wien まで来たからこそこのような別地の学者と語りあ えるということの幸福をかみしぬたものであった．

\section{4. 本 会 議}

本会議に打ける E-1.3.2 部会は 6 月 21 日午後の $\mathrm{A}$ 会 場で開催された。座長は Dr. Wyszecki であって專門 委員会の委員長, 幹事の Mr. Münch, Dr. Richter と ともに議長席に着いた，予備会議ですでに白熱の論義は すんでしまっているので，ここではそれを復習するだけ である. CIE 暫定方法の英独仏文案が用意されていて, これの説明, Miss Nickerson の IES 小委員会の原案 作成経過の説明の後, 各国からの意見を求めるといらこ とになった。

まず Dr. Crawford はスペクトルバンド法を述べ, 数人の原案を支持する演説の間に Dr. Einhorm も専門 委員会のときと同様なことを述べに壇上に上った．

本会議で一席弁じないとやはり公式の意見にはならな いのかなどと独り勝手なことを考えていると，座長の声 が耳にはいってきてがく然とした．「この問題は日本に も大いに意見があるはずである. 本会には Expert Dr. Azuma の代理で Dr. Mori がきている. その意見をう かがいたい.」といらのである.もちろんいいたいこと が無いわけではない，意を決して立ち上がり文案を考え るた㛉にできるだけゆっくりと壇上へと歩んだ。ここで 筆者が簡単に E-1.3.2の成果に敬意をはらった後述べた こと, 少なくとも述べようと努力したいことは次の内容 である。

私はこの方法に “暫定”といら意味において賛成す る。しかしこの中にはまだ満足できないものが含まれて いる．それは一般演色評点と特殊演色評点とに異なった 式を用いていることであり，とくに一般演色評点では試 験色の明度変化を無視していることである．将来この方 法が改善され一般演色評点も特殊演色評点と同じ式で扱 われ，ともに試験色の明度変化を考慮するものとなるこ とを希望する。

いい終えて席に帰ってからまだ続いた意見の発表は今 はもう記憶に残っていない. Münch 氏の個人論文（文 献紹介参照) は演色評価方法が決まったあとのこの実用 という意味で意欲的なものであった. 最後に座長が CIE 暫定方法をまとめ上げた委員長の労（patient という語 が印象的にひびいた）をたた竞よらといってめでたく閉 会となった．思えば専門委員会において大勢に従って米 国案を主とし，自国案を従とするよらな原案をまとめた Münch 委員長の態度はまことに立派であったし，また 本会議に拈いて多くの意見を引き出しながらも原案承認 
のすじを通した Wyszecki 座長の議事進行もみごとな ものであった。

\section{5. 会議場の外で}

筆者にとっては会議場外での諸学者との談話はきわめ て有益であった，その機会はその気にさえなれば休喤時 間, 昼食時そして各種の社交行事に参加するときにいく らでも見つけることがでさる。

Miss Nickerson とお話ししたときに彼女の豊富なデ 一タ（一般演色值には明度ずれを計算に入れても結果的 には IES 方法とほとんどかわらないものしかでないと いらことを示したもの）の詳しい説明をらけて，ようや く今回の決定に至った経過がよく理解できて, 専門委員 会の最初から出席しなかったこと, 拈よ゙本会議で結果 的には多少ピントはずれの意見を述べてしまったことが 悔まれた，しかし筆者の意見も十分にわかっていただく ことができて, 会議後の文案の修正には多少とも真献で きたと考えている．また Mr. Münch が今度の方法は 実によくまとめられたと本当にほこらしげに語られた顔 付は今も忘れることができない.

\section{6. 終わりに}

S-1.2 での筆者の講演での経験, 各種の社交行事のこ と，とくに最後の扸れパーティでの楽しいふんい気な どまだ打伝えしたいことは少なくない。しかしまとまり もなく E-1.3.2 のことを述べているうちに紙数も尽き てしまった。
終わりに一言述べさせていただけば，筆者にとって今 回の CIE 総会に出席できたことはきわめて有益なこと であったこのような状態を作って下さった諸先輩に心 からの感謝をささげたい，そして今後ともできるだけ多 くの方が出席されることを願いたい，本文にも述べたよ らに総会にお㚈る Presessionの果たす役割はきわめて 大きいので，今後はこれに多くの方が出られ，十分な準 備の下に日本の学界の意志が国際的な決定に反映するよ らな意見を発表されるよらになることを期待する。実際 に今回抎いした学者の中には Presession にさ出れ ばよいんだといわれて本会議をまたずに帰国された方さ えあった，しかし日本からの出席者は本会議の空気も知 る必要があろらし, とくに各種行事の最中に世界中の学 者と交歓できる絶好の機会も逃がすことはできないであ ろう. 今でも尊敬できる多くの学者と語り合ったときの 一景一景が昨日のことのように思い出される。

\section{参 考 文 献}

(1) CIE Compte Rendu (1948) 18

（2）色彩科学協会 “色彩科学ハンドブック”南江堂 (1962) pp. 337 353

(3) J. L. Ouweltjes : Farbe 9 (1960) 207

(4) Subcommittee on Color Rendering of the Light Sources : Ill. Eng. 57 (1962) 471

(5) DIN 6169 Blattz 2 Entwurf 1962; Farbe 10-5/6 (1961) 342
照明界のトピックス

\section{目と道路交通 研究会開催さる}

去る11月 8 日, 第 3 回「日と道路交通」研究会が東京 に打いて開催された。会場は東京医科大学病院同空会館 ホール, 参加者約 90 名, 14 件の講演がなされた。演題 は次のとおりである。松尾治亘：フランスにおける自動 車運転免許の視覚検査, 篠塚清志: 英米雨国における交 通事情について, 関亮: 欧州に打流る交通事情, 阿部信 博ほか: 交通事故による眼障害の統計的観察, 飯沼㦑注 か：げん輝の一検查法. 鈴村昭弘：まぶしさと見え方. 山地良一ほか：長距離トラック運転手のポート・グレア・
テスト成績とアダプチノールの効果について, 堀正剛ほ か：動きの視認力に及汸す影響。蒲山久夫伍か：自動 車道路路面に対与る視力について.山地良一伍か：トン ネル照明と動体の見え方およびアダプチノールの影響に ついて. 斉藤満 : 道路照明基礎実験に関する二, 三の問 題, 石川光一郎ほか：道路照明用各種光源の量的視野に 及ぼす影響について，山地良一ほか：道路照明用各種光 源の中心外視力に及ぼす影響について, 市川宏ほか： 自動車運転免許用色覚検查法について。

各講演について活発な討論があり盛会であった。なお 午後 3 時より有志のほうが集まり, 自動車免許証交付時 の目の検查基準に関する座談会が開かれ, 現行の目の検 査基準および検査方法に対する批判が行なわれた。

次回は昭和 39 年 4 月に東京において開催の予定であ る. 